\title{
岬回りでの間欠的漂砂に起因する 広域海浜変形
}

\author{
宇多 高明 1 -大木 康弘 2 -三波 俊郎 3 -住田 哲章4 \\ 1正会員 一般財団法人土木研究センター常務理事なぎさ総合研究室長兼 \\ 日本大学客員教授理工学部海洋建築工学科（干110-0016 東京都台東区台東1-6-4） \\ E-mail: uda@pwrc.or.jp \\ 2 (株) 水圈科学コンサルタント（干145-0064 東京都大田区上池台1-14-1 名伸ビル4F） \\ E-mail: ooki@lasc.co.jp \\ 3海岸研究室（有）（干160-0011 東京都新宿区若葉1-22 ローヤル若葉301） \\ E-mail: GGB01566@nifty.com \\ 4 (株) 水圈科学コンサルタント（†145-0064 東京都大田区上池台1-14-1 名伸ビル4F） \\ E-mail: sumita@lasc.co.jp
}

\begin{abstract}
茨城県大津漁港の防波堤による波の遮蔽域では, 過去に大量の土砂が堆積したが，堆砂量は天妃山以北 の神岡上・磯原海岸の侵食土砂量よりはるかに大きかった。この原因として, 砂が南側区域から運び込ま れた可能性が考えられたことから，大津漁港〜高戸岬を対象として空中写真による汀線変化解析を行うと ともに，そこでの海浜土砂変化量を算出した。 この結果，1975～2009年間に，大津漁港〜天妃山間（全長 $4.5 \mathrm{~km})$ では7.0× $10^{5} \mathrm{~m}^{3}$ 土砂量が増加したのに対し, 天妃山〜高戸鼻間 $(13 \mathrm{~km})$ では $8.4 \times 10^{5} \mathrm{~m}^{3}$ の減少 であり，両者はほぼ対応を示した。これより天妃山の岩礁は沿岸漂砂の固定境界とはならないことが分か った.
\end{abstract}

Key Words : longshore sand transport, wave-shelter zone, Otsu fishing port, sand budget

\section{1. はじめに}

過去，茨城県大津漁港の南側に位置する神岡上海岸で は，漁港防波堤の建設に伴って著しい侵食が起こる一方， 防波堤による波の遮蔽域では大量の砂が堆積した1)。こ の海岸の南側を区切る位置には天妃山の岩礁があり，そ れに隣接して大北川が流入している．天妃山の岩礁は大 北川に対する河口導流堤の役割を果たしており，河口は 常にこの岩礁の南側に固定されている.この岩礁は水深 $6 \mathrm{~m}$ 付近まで張り出しており, 常時波浪に対しては突出 した岩礁が沿岸漂砂阻止効果を有していると考えられる. しかし，この付近の海岸での波による地形変化の限界水 深はほぼ9 $\mathrm{m}^{2}$ と深いので，高波浪時には天妃山の岩礁を 越えて一部の浻岸漂砂が移動可能と考えられる. 最近, 宇多ら ${ }^{3)}$ は，2011年3月11日の大津波による神岡上海岸の 護岸の被災原因について考察し，この海岸では侵食が進 んだ結果護岸前面が急深であったことが護岸被災の一因 をなしたことを明らかにした. しかし宇多ら”の研究で 対象とした大津漁港〜天妃山の区域では，土砂収支がと
れておらず堆砂量が侵食量より大きかった。これを考慮 すると, 天妃山の岩礁は通常波浪時には沿岸漂砂を阻止 するが，高波浪時には天妃山の南側海岸から北側への沿 岸漂砂を完全に阻止するものではなく，大津漁港の防波 堤による波の遮蔽域での大量の堆砂は，天妃山以南の区 域（天妃山〜高戸鼻）から運び込まれた可能性が高いと 推察された。司代ら ${ }^{2}$ は，大津漁港から高戸鼻まで約 $17.5 \mathrm{~km} の$ 海岸線全線を対象として汀線変化を調べ，天妃 山を越える沿岸漂砂の可能性を指摘したが，定量的検討 は行っていない. このことから, 本研究では, この区域 全体を対象として，空中写真に基づく汀線変化分析を行 うとともに, 既往研究で得られている神岡上海岸での漂 砂の移動高8.3 $\mathrm{m}^{4}$ を考慮して海浜土砂量の変化を算出し, この区域の中央に位置する天妃山の岩礁を通過した沿岸 漂砂量の定量的評価を行った。

\section{2. 大津漁港の主要外郭施設の建設経緯}




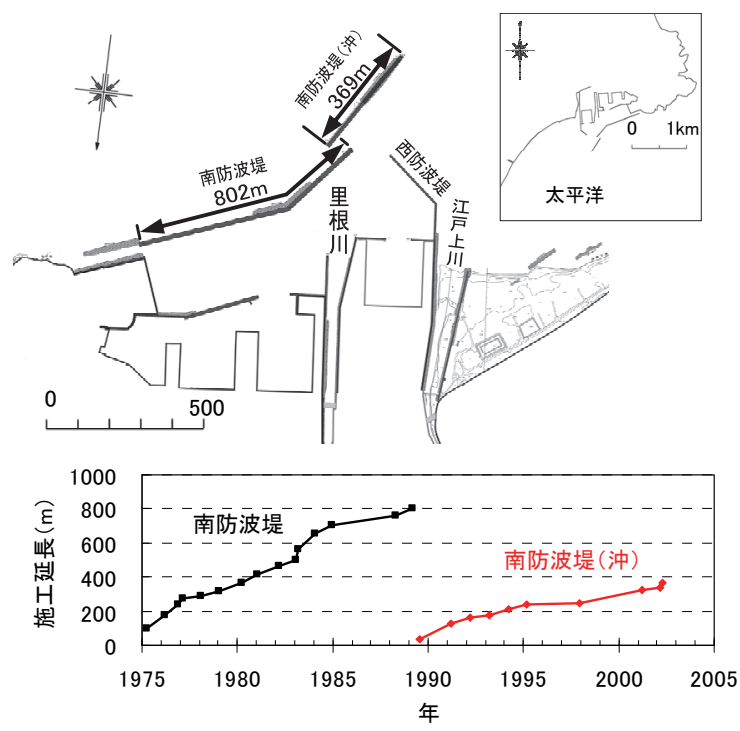

図-1大津漁港の主要外郭施設施工経緯

対象区域での海浜変形に影響を及ぼす可能性が高いの は大津漁港の防波堤である。そこでまず大津漁港の防波 堤の建設経緯について調べた。図-1は防波堤の配置と防 波堤の施工延長を示す．波の遮蔽域形成に預かる主要な 防波堤は，南防波堤，および南防波堤とわずかな開口部 を残してその沖に369 m伸ばされた南防波堤（沖）であ る.これらの防波堤は東側からの入射波に対し，防波堤 の南側海域に大きな波の遮蔽域を形成することとなった。 防波堤の建設経緯としては，まず南防波堤が1975年から 1989年までに802 m伸ばされた。その後1989年から2002年 までに南防波堤（沖）が369 m伸ばされた. なお，図-1 には大津漁港に隣接して流入する里根川と江戸上川河口 の位置も示すが，これらの河川はごく小規模で流入土砂 は無視できる.

\section{3. 大津漁港〜高戸鼻間の広域汀線変化}

研究対象は，茨城県北部に位置する岩石海岸（五浦海 岸）の南側に隣接する大津漁港から高戸鼻まで $17.5 \mathrm{~km} の$ 海岸である.この区域の1961〜2009年における海岸線の 変遷について空中写真を基に調べた。同種の検討として, 宇多ら ${ }^{1)}$ は大津漁港〜天妃山の区域を対象として1975年 と1992年の空中写真の比較により汀線変化を調べた。ま た，最近，宇多ら゙，同じ区域について調査期間を 2009年まで広げて分析を行った，本研究では，調査区域 をさらに南側に広げ，天妃山〜高戸鼻間を対象として検 討を進めた. 調査対象区域の延長は $17.5 \mathrm{~km}$ 長いので, 天妃山を境に南北に二分し，天妃山以北・以南の区域に ついて論じる.

\section{(1) 天妃山以北の区域}

まず，1961年には沿岸に大規模な施設はなく，五浦海 岸の岬の陰に大津漁港の小規模な防波堤が延びていたの みであり，汀線は30〜60 mの浜幅を持って大津漁港から 天妃山まで沿岸方向に滑らかに延びていた(図-2(a)).

2009年になると，図-2(b)に示すように大津漁港の沖防波 堤が「く」の字形に大きく伸ばされ，防波堤による波の 遮蔽域で大量の砂が堆積し，三角形状の堆積域が形成さ れた．江戸上川河口右岸での1961年基準での汀線前進量 は320 mに達した。これと対照的に，防波堤による波の 遮蔽域の南側に位置する神岡上海岸では侵食が進み前浜 が全く消失した.さらにその南側に隣接する磯原海岸で は，人工リーフ2基と離岸堤4基が造られてようやく海浜 が維持される状況となった.

対象区域の汀線変化を定量的に論ずるために，1961〜 2009年に撮影された10組の空中写真を用いて汀線変化を
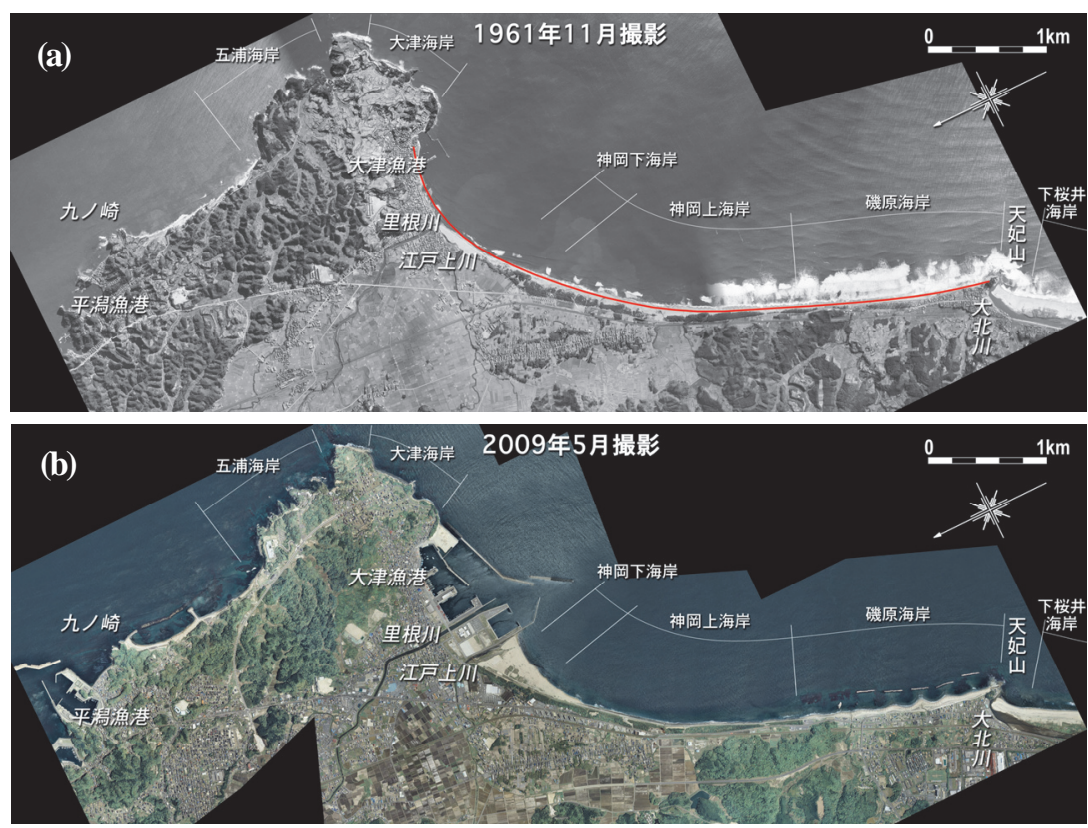

図-2大津漁港～天妃山間の空中写真（1961年vs. 2009年） 
調べた．その際，大津漁港の沖防波堤の形状は1991年頃 より大きく変化しているので，防波堤の規模が小さかっ た1961〜1990年，沖防波堤の建設が進められた1990〜 1999年，およびそれ以降の1999〜2009年の3時期に区分 し，1961年の空中写真（図-2(a)）に赤線で示寸ように, 海岸線に沿って滑らかに引いた線を基準とし，この線か ら各年の汀線までの沖向き距離を読み取った.

図-3は1961～1990年の汀線変化を示す．1961年には基 準線とほぼ平行に伸びていた汀線が，大津漁港の防波堤 の建設に伴い波の遮蔽域が形成されたために，この遮蔽 域では汀線が三角形状に前進した。この期間の最大汀線 前進量は302 mであった。これと同時に，神岡上海岸の X=4.6〜 7.0 kmでは汀線が後退し，護岸消波工が波に曝さ れる状態となった. 一方，南部の磯原海岸では離岸堤の 建設とともに砂が堆積し舌状砂州が形成された.

同様に1990～1999年における汀線変化を図-4に示す. この間では，江戸上川河口右岸に防波堤が伸ばされ，ま

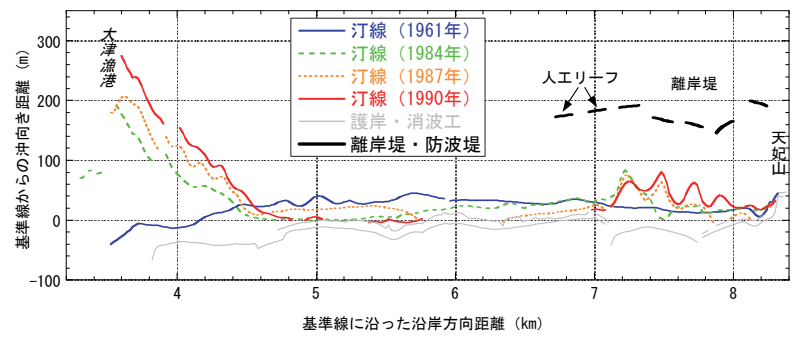

図-3 大津漁港〜天妃山間の汀線変化（1961-1990年）

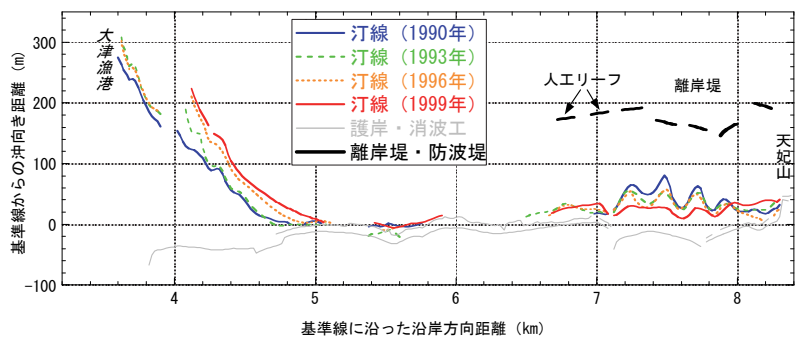

図-4 大津漁港〜天妃山間の汀線変化（1990-1999年）
た沖防波堤の建設も行われた。江戸上川河口右岸の防波 堤は長さが長く，北向きの沿岸漂砂を阻止したため，防 波堤の南側では汀線前進が続いたが，防波堤北側では堆 砂がほぼ生じなくなった。この間で注目されるのは，沖 防波堤による波の遮蔽効果の増大のために，磯原海岸の 離岸堤背後に形成されていた舌状砂州の砂もまた北向き に運び去られて汀線が後退したことである．汀線近傍に 設置された透過性離岸堤と比較して大津漁港の不透過防 波堤による静穏域形成がはるかに勝るため，いったん磯 原海岸の離岸堤背後に堆積した砂もまた北向きに移動し たと推察される.

さらに，図-5は1999年以降の汀線変化を示す．1999年 までに大津漁港の沖防波堤による波の遮蔽域で汀線が最 大230 m前進したが，その後沖防波堤がさらに119 m伸ば されたことから遮蔽域が広がり，2002年までにほぼ安定 に達していた汀線が再び変形して北端では汀線が339 m 前進し，この変形に必要な砂が南部から運び込まれたた め堆積域の南側では侵食が進んだ.

\section{(2) 天妃山以南の区域}

天妃山〜高戸鼻間約8 km区域の1961年と2009年の空中 写真を図-6に示す。対象区域のほぼ中央には塩田川が流 入し，塩田川河口を中心として海岸線がやや突出してい る.このため塩田川河口を中心とした南北約 $4 \mathrm{~km} の 2 つ$ の弓状の海岸線に区分される.これらの空中写真の比較

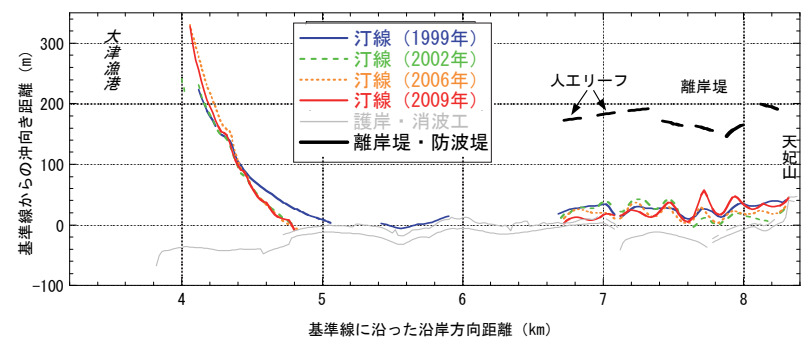

図-5大津漁港〜天妃山間の汀線変化（1999-2009年）

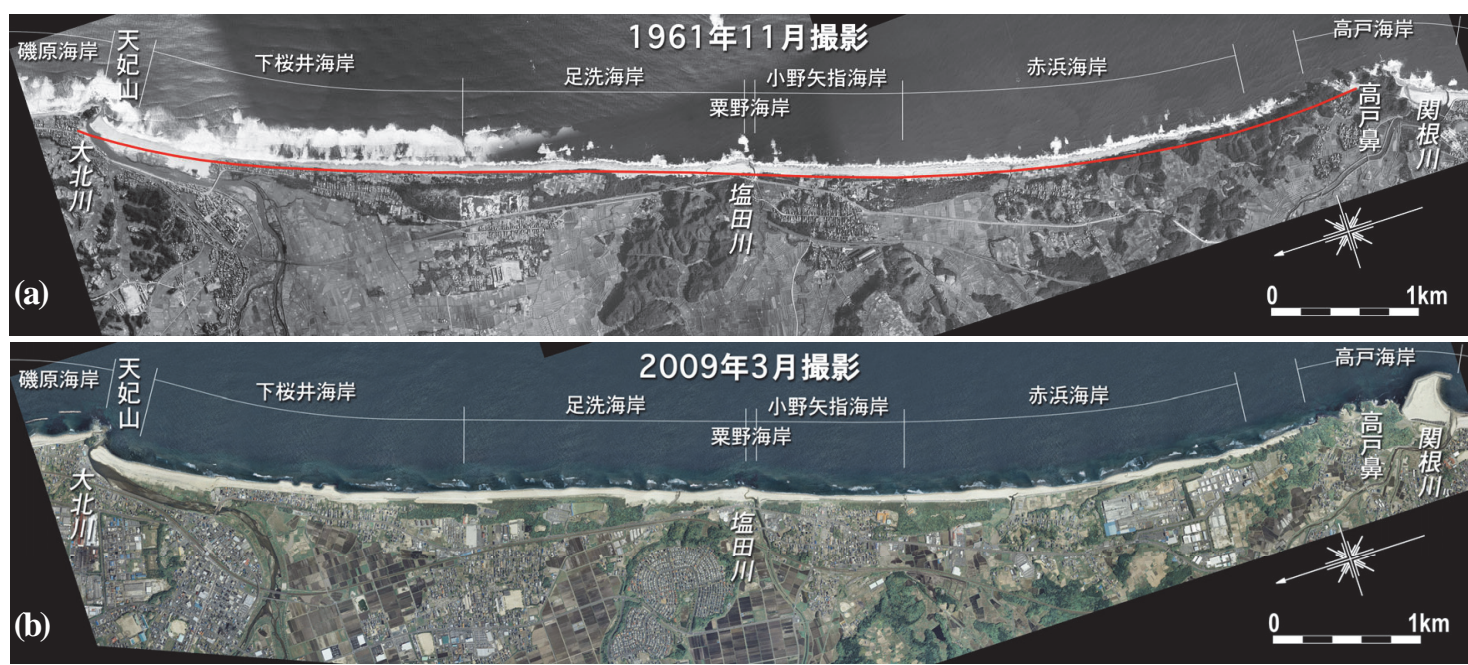

図-6天妃山〜高戸鼻間の空中写真（1961年vs. 2009年） 


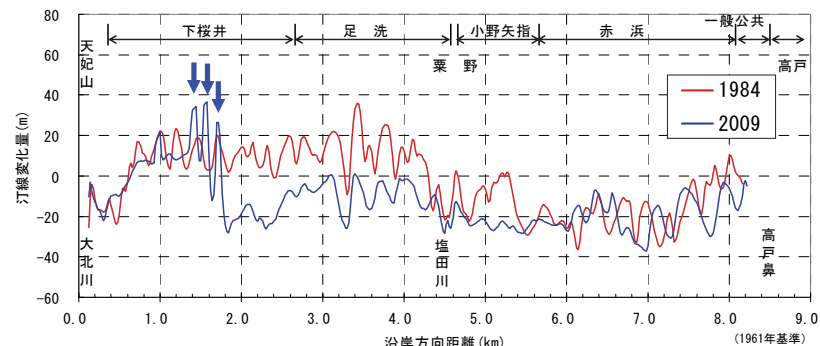

図-7天妃山〜高戸鼻間の汀線変化（1984年vs. 2009年）

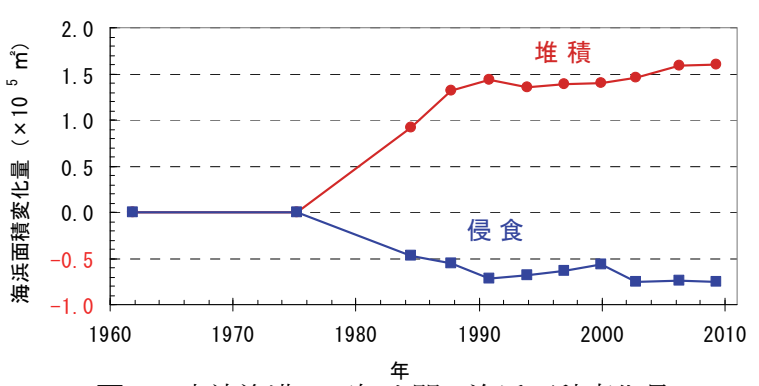

図-8大津漁港～天妃山間の海浜面積変化量

によれば，天妃山以北と異なり1961年と2009年とで汀線 形状には大きな変化はなく, 連続的な砂浜海岸が広がっ ていた．なお，対象区域北端の天妃山周辺の海岸状況に ついて図-6を基に調べると，図-6(b)に示す2009年の空中 写真では静穏であったため，天妃山を挟んで南北の砂浜 は独立に見えるが，図-6(a)に示す1961年の空中写真は高 波浪時の撮影であったため, 天妃山の沖合を含んで砕波 の白濁域に含まれている。これらを考慮すれば，通常波 浪時には天妃山はほぼ固定境界を与えるが，高波浪時に は沿岸漂砂が岬沖を通過可能と考えられる。 これは, 樋 ロら ${ }^{5}$ の現地調査に基づく指摘と一致している.

天妃山〜高戸鼻の区域では，1984〜2009年の9時期に 空中写真が撮影されているが，それら全体を示すと煩雑 になって特性が読み取りにくいので，これを避けるため に後述の海浜面積の長期的トレンド（図-9）に示すよう に, 変動が小さく全体的傾向をよく示寸と考えられる時 期（1984年と2009年）を選定し，これらの時期の天妃山 から高戸鼻間の汀線変化を調べた結果を図-7に示す.

2009年までの汀線変化に見られる下桜井海岸の3箇所 の矢印で示寸汀線変化は侵食対策として離岸堤が造られ, そこで舌状砂州が発達したことによるの. この付近を除 けば，汀線は測定年ごとに沿岸方向に大きな変動を有し ているものの，下桜井海岸のほぼ中央部から小野矢指海 岸の間で平均約15 m汀線が後退している. これより砂が この区域外一と運び去られた可能性が高いことが分かる。 以下ではこれらの定量的評価を行った.

\section{4. 広域土砂収支}

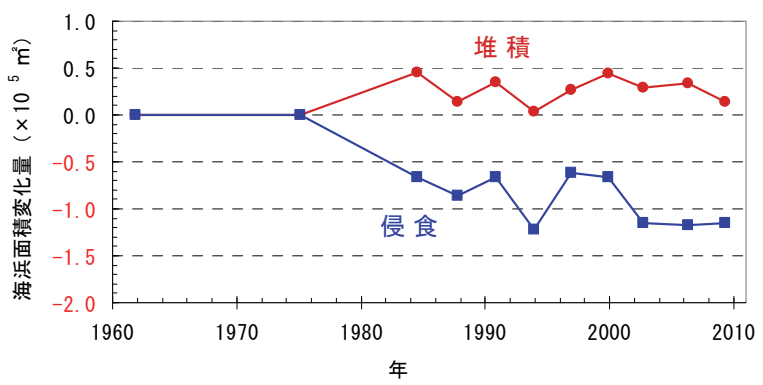

図-9天妃山〜高戸鼻間の海浜面積変化量

図-8は，天妃山以北の区域に対する1961年の汀線を基 準とした前浜の増加量と減少量の経年変化を示す. 大津 漁港の南防波堤は1975年から建設されたが，それと同時 に波の遮蔽域では堆積が進んで海浜面積が増加した。波 の遮蔽域での前浜面積は1961〜1990年で約1.43× $10^{5} \mathrm{~m}^{2}$ 増 加したが，その後は微増傾向に変わった。同時に，侵食 域の前浜面積も1961～1990年に大きく減少し，その後は ほぼ一定值に近づいた。これはこの区域の侵食域では護 岸が露出し，削るべき砂浜がほとんど消失したことによ る. 総量比較として, 1961〜2009年の総堆積面積1.60× $10^{5} \mathrm{~m}^{2}$ に対し, 総侵食面積は $0.76 \times 10^{5} \mathrm{~m}^{2}$ であった. 神岡 上海岸では漂砂の移動高が $8.3 \mathrm{~m}^{4}$ と得られているので, この值を海浜面積の変化量に乗じると, 総堆積量は13.3 $\times 10^{5} \mathrm{~m}^{3}$ ，総侵食量は6.3 $\times 10^{5} \mathrm{~m}^{3}$ となった。 さらに, 1984 年から2009年の間に，大津漁港においては里根川と江戸 上川河口に挟まれた区域の砂浜は埋立地となったが，埋 め立てられた砂浜の面積は約 $0.73 \times 10^{5} \mathrm{~m}^{2}$ である. これ に漂砂の移動高8.3 mを乗じると, 埋め立てされた砂の 総量は6.06 $\times 10^{5} \mathrm{~m}^{3}$ と推定される. この量の砂は固定化 され，波の作用で再び移動するのが困難となった．

以上のように大津漁港〜天妃山間では堆積量が侵食量 より大きく，土砂収支は取れていない，当海域では沖合 は平坦で, 波による地形変化の限界水深はほぼ9 mにあ り，また，一般に土砂損失の要因となる海底谷なども存 在しないこと2) から, 漂砂系としては沿岸方向の区域を 対象と考えればよいことを考慮すると，天妃山の岩礁が 沿岸漂砂に対する固定境界となっていない可能性が高い ことを示唆し, 土砂量の増加は天妃山以南の区域から砂 が運び込まれたためと考えざるを得ない，そこで，天妃 山〜高戸鼻間の延長約13 kmの海岸についても同様な検 討を行った．結果を図-9に示す。この区域では海浜面積 の増加量に対して減少量のほうが大きく，1975～2009年 での海浜面積増加量 $0.14 \times 10^{5} \mathrm{~m}^{2}$ に対し，同じ期間での 侵食面積は $1.15 \times 10^{5} \mathrm{~m}^{2}$ となった。 ネットでは $1.01 \times 10^{5}$ $\mathrm{m}^{2}$ の海浜面積の減少であり, これに漂砂の移動高を乗 じると，ネットの土砂減少量は $8.4 \times 10^{5} \mathrm{~m}^{3}$ となった。こ れは大津漁港〜天妃山間でのネットの土砂増加量 (7.0 $\left.\times 10^{5} \mathrm{~m}^{3}\right)$ と比べると20\%大きいがかなり近い值である. 


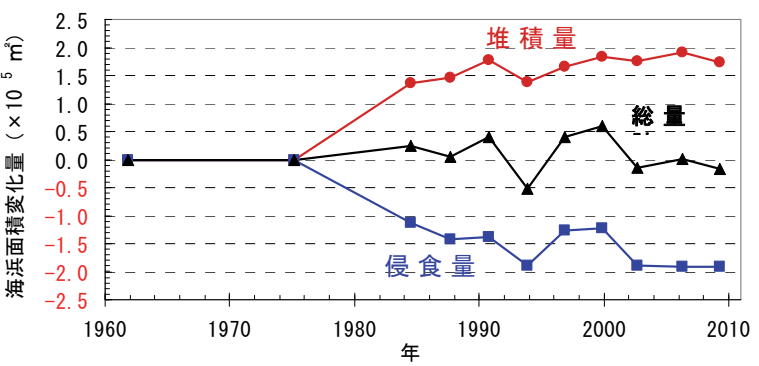

図-10 大津漁港〜高戸鼻の海浜面積変化量

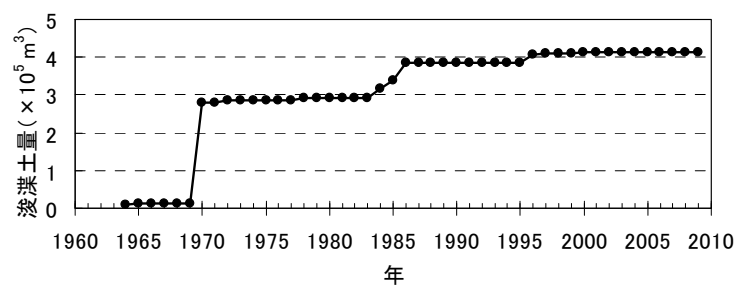

図-11 大津漁港内の浚渫履歴

図-10は，大津漁港から高戸鼻まで全域を対象として 海浜面積の増加量と減少量を算出した結果である. 2009 年までの変化に着目すれば，全域を対象とすると海浜面 積の増加減少量はほぼ釣り合っており，ネットでは0.16 $\times 10^{5} \mathrm{~m}^{2}$ 海浜面積が減少したにとどまる. しかし, 海浜 面積の増加量は $1.74 \times 10^{5} \mathrm{~m}^{2}$, 減少量は $1.90 \times 10^{5} \mathrm{~m}^{2}$ であ って, 海浜面積の減少量のほうが増加量よりも $0.16 \times 10^{5}$ $\mathrm{m}^{2}$ 大きい結果となった。 土砂量に換算すれば2009年まで に1.34 $\times 10^{5} \mathrm{~m}^{3} の$ 土砂量の欠損が生じたことになる.

海浜の土砂収支の検討にあっては，漂砂の系外への砂 の移動を無視することはできない.そこで大津漁港での 浚渫の経緯を調べた. 結果を図-11に示す.1964年以降 の総浚渫土砂量は $4.12 \times 10^{5} \mathrm{~m}^{3}$ であって, 南防波堤の建

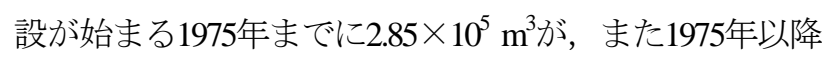
には $1.27 \times 10^{5} \mathrm{~m}^{3}$ が浚渫された。南防波堤建設による波 の遮蔽域への沿岸漂砂は1975年以降活発化したと考えら れるので, 1975年以降の浚渫量が波の遮蔽域へと運ばれ た土砂量に相当すると考えられる。このとき $1.27 \times 10^{5}$ $\mathrm{m}^{3}$ の浚渫量は, 上述の海浜土砂量の欠損量 $1.34 \times 10^{5} \mathrm{~m}^{3}$ とほぼ等しい. よって海浜土砂が防波堤背後へと運び込 まれたことが主な侵食原因となったと推察される。なお, 南防波堤建設以前の浚渫は主として漁港泊地の掘削とし て行われたと考えられる.

\section{5. 短い岬 (天妃山) 周辺での漂砂機構}

天妃山は長さの短い岬であるが，この岬は大北川に対 して河口導流堤として機能し，河口を常時岬の南側に固 定する効果を有している. 長さが短いため沿岸漂砂を完 全に阻止することはできないが，部分的な阻止は岬の両 側で振動モードの汀線変化があることから見てとれる.

図-12は大北川河口部が撮影された空中写真から，比 較的静稳時に撮影された3時期の空中写真を選んで示す.
土木学会論文集B3 (海洋開発), Vol. 69, No. 2, I_802-I_807, 2013.

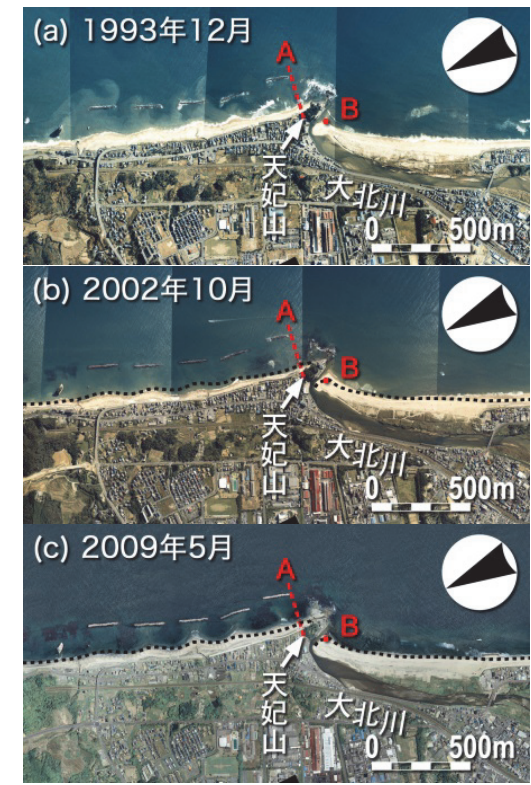

図-12 大北川河口部の空中写真

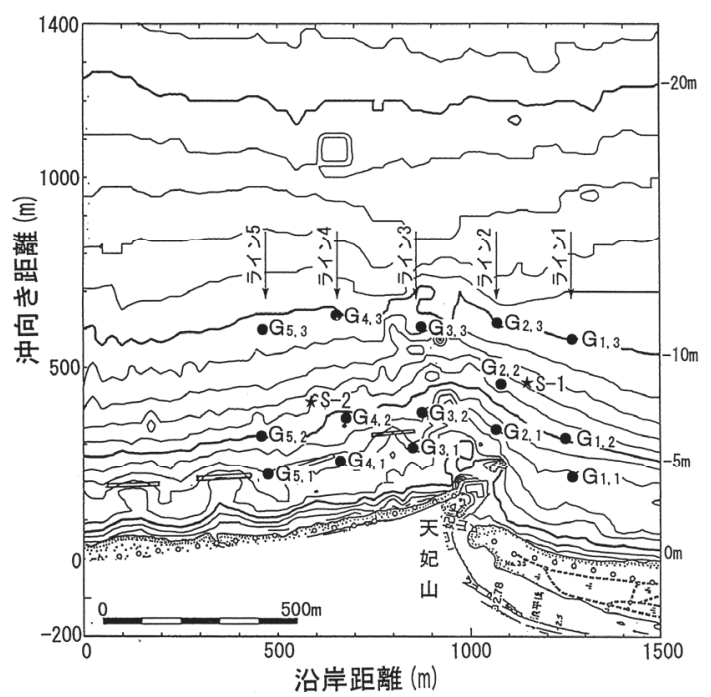

図-13 天妃山周辺の1993年の深浅図 ${ }^{7}$

困中，天妃山の北側直近に測線Aを，また河口右岸砂州 の最突出点にBを定める。まず，1993年と2002年の比較 では，測線A上で浜幅が30 mから10 mに狭まったが，こ れと同時に右岸河口砂州では堆積が起こり，B点は河口 の澪筋に沿って砂浜が40 m沖へと広がった. また，天妃 山北側での汀線後退域は，測線A以北の全域で見られる。 このことから，この期間では北向きの沿岸漂砂が卓越し ていたことが分かる.さらに，2002年と2009年の比較で は，測線Aでの浜幅は10 mから40 mと広がる一方，右岸 砂州は後退し，B点付近の砂浜は河口の澪筋に沿って25 m狭まった. この場合の変化は，南向きの沿岸漂砂の作 用によると考えれば無理なく説明できる.このように天 妃山周辺では沿岸漂砂の向きが南向き・北向きと変動し, それに合わせた汀線変化が起きていることが分かった. また，いずれの写真でも天妃山沖70 mで斜めに伸びた岩 礁背後の水深は小さく, 2009年5月の写真に示すように この岩礁背後で堆砂が起きている場合もある.

図-13は田中らかが示した天妃山周辺の1993年の深浅図 


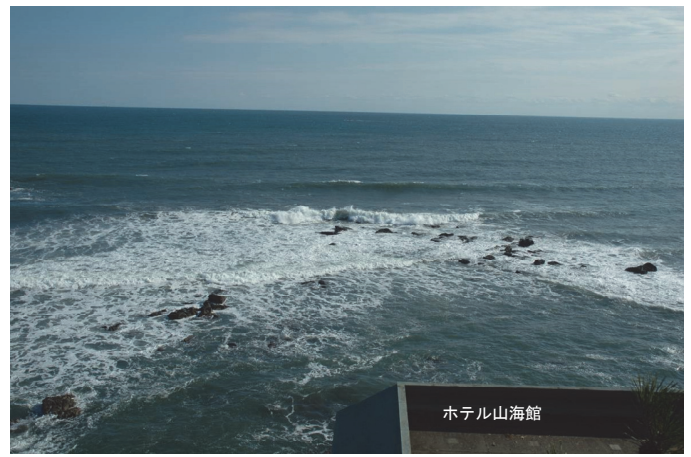

図-14天妃山山頂からホテルの護岸前面の 海岸を望む（2010年11月27日）

を示す．天妃山沖で斜めに延びた岩礁周辺の水深は2-3 mと小さい. 図-14は，2010年11月27日に天妃山山頂かっら ホテルの護岸前面の海岸を望んだものである．常陸那珂 港での波浪観測によれば当日の入射波高は $2.1 \mathrm{~m}$ (周期 $7.4 \mathrm{~s}$ ）であったが，この条件下で沖合に斜めに伸びる岩 礁帯全体が砕波帯に含まれている。この付近における波 による地形変化の限界水深はほぼ-9 mにある.これが妥 当なことは図-13においてバーの発達する浅海域を除い て-9 m以浅の等深線が汀線とほぼ平行に伸びていること からもこの水深付近まで活発な漂砂が生じていることが 理解できる.この条件では先に述べた天妃山沖の岩礁の 水深は小さく，通常波浪の作用時には天妃山の岩礁を沿 岸漂砂が横切って流れることは困難としても田中らかが 示したように南寄りの方向から高波浪が入射した場合に は天妃山の岩礁帯を横切る北向きの沿岸漂砂が起こり得 ると推察される.ただし，この現象がいつ起こるかにつ いての情報がないことから，その定量化については今後 の課題として残された.

\section{6. 結論}

1975～2009年での海浜土砂収支を検討したところ，大 津漁港〜天妃山の4.5 km区間では土砂堆積量が侵食量よ
り大きく, ネットでは7.0 $\times 10^{5} \mathrm{~m}^{3}$ の土砂量の増加が起き た.これに対し，天妃山から高戸鼻まで13 km区間では 侵食量が堆積量より大きく，同じ期間におけるネットの 土砂減少量は $8.4 \times 10^{5} \mathrm{~m}^{3}$ であった.この結果は，この区 域の海岸保全を考える場合，天妃山の岩礁を沿岸漂砂の 固定境界と考えることはできないことを意味している.

大津漁港の防波堤による波の遮蔽域形成に伴って誘起 された北向きの沿岸漂砂が，天妃山の岩礁を通過して北 側区域へと流れ込み，それが大津漁港の防波堤遮蔽域に トラップされて元に戻ることができないという現象が起 きている. すなわち, 大津漁港の過剰な土砂堆積の逆問 題として下桜井海岸以南の侵食問題を位置付ける必要が あり，海岸保全と漁港の維持の両立を図るには広域土砂 収支を念頭に進めなければならないことが明らかである。

\section{参考文献}

1) 宇多高明, 三波俊郎, 石川仁憲 : 海岸の急速な人工化 を防ぐ上で必要な災害復旧制度の改良, 海岸工学論 文集，第 53 巻，pp.1321-1325, 2006.

2) 司代 明, 川村哲也, 田中正博, 大熊義夫, 宇多高明 : 茨城県北部大津漁港〜高戸海岸における広域海浜地 形変化の現地観測, 海岸工学論文集, 第 44 巻, pp.656660, 1997.

3) 宇多高明, 酒井和也, 星上幸良: 侵食海岸を襲った 2011 年大津波による護岸の破壊-茨城県北部神岡上海 岸の事例-, 水利科学, No. 325, pp.15-29, 2012.

4) 宇多高明: 日本の海岸侵食, 山海堂, p.442, 1997.

5) 樋口豊久, 西澤 学, 川村哲也, 宇多高明: 間欠的な沿 岸漂砂移動を伴う岬 (岩礁) 周辺における海浜地形 変化の現地観測, 海岸工学論文集, 第 44 巻, pp.626-630, 1997.

6) 宇多高明, 大木康弘, 住谷廸夫 : 茨城県下桜井海岸で の異常な斜め入射波による急激な侵食, 海洋開発論文 集, 第 24 巻, pp.1297-1302, 2008.

7) 田中正博, 阿部光信, 宇多高明 : 砂面計・鉄筋棒を用 いた岩礁周辺での海底地形変動の現地観測, 海岸工学 論文集, 第 44 巻, pp.621-625, 1997.

\section{LARGE-SCALE BEACH CHANGES CAUSED BY INTERMITTENT SAND TRANSPORT AROUND A ROCKY POINT}

\section{Takaaki UDA, Yasuhiro OKI, Toshiro SAN-NAMI and Akinori SUMITA}

A large amount of sand was deposited in the wave-shelter zone behind the offshore breakwater of Otsu fishing port in Ibaraki Prefecture, which was much smaller than the eroded volume of sand on the Kamioka-kami and Isohara coasts located south. Because the possibility of sand transport from the further south coasts was considered as the cause, the shoreline changes in the entire study area were analyzed using aerial photographs along with the analysis of the change in volume of sand on coasts. As a result, in a period between 1975 and 2009, the volume of sand has increased by $7.0 \times 10^{5} \mathrm{~m}^{3}$ in an area of $4.5 \mathrm{~km}$ length between Otsu fishing port and the Tenpisan Rock, whereas the volume of sand has decreased by $8.4 \times 10^{5} \mathrm{~m}^{3}$ in an area of $13 \mathrm{~km}$ length between the rock and Takado Point, indicating that the Tenpisan Rock is not a solid boundary for longshore sand transport. 